\title{
The Personality Of Ayyas In Bumi Cinta Novel By Habiburrahman El-Shirazy
}

\author{
Nanang Sugianto ${ }^{1}$, Tri Setianingsih ${ }^{2}$ \\ ${ }^{1,2}$ Universitas Pendidikan Mandalika \\ trisetianingsih@ikipmataram.ac.id
}

\begin{abstract}
This research aimed to find out the Personality of Ayyas in Bumi Cinta novel by Habiburrahman El Shirazy. The method applied in this research was qualitative method. The object of this research was the personality of Ayyas' character in Bumi Cinta novel by Habiburrahman El Shirazy through psychology review. The technique used in collecting the data was library research. The process of data analysis was data reduction, data display and conclusion drawing. The result of this study was found out that the personality of Ayyas was more dominant influenced by the superego. Based on the result of the study, it could be concluded that the personality of Ayyas influenced by the superego seems when Ayyas defended himself in the sanctity and his faith in the midst of the storms of free life country, having a firm belief and faith to God, Ayyas remained confident and believe in the grace of God to His people. Although there were some people who did not acknowledge the existence of God, Ayyas was always cling to the obligations of religion, implementing everything that God approves, and stay away from all His prohibitions, and reluctant to commit sin and sinners, willing to sacrifice for the sake of religion and give helping.
\end{abstract}

Keywords: Personality Structure (id, ego, and superego)

Abstrak. Penelitian ini bertujuan untuk mengetahui Kepribadian Ayyas dalam novel Bumi Cinta karya Habiburrahman El Shirazy. Metode yang digunakan dalam penelitian ini adalah metode kualitatif. Objek penelitian ini adalah kepribadian tokoh Ayyas dalam novel Bumi Cinta karya Habiburrahman El Shirazy melalui kajian psikologi. Teknik yang digunakan dalam mengumpulkan data adalah penelitian kepustakaan. Proses analisis data adalah reduksi data, penyajian data dan penarikan kesimpulan. Hasil penelitian ini diketahui bahwa kepribadian Ayyas lebih dominan dipengaruhi oleh superego. Berdasarkan hasil penelitian dapat disimpulkan bahwa kepribadian Ayyas yang dipengaruhi oleh superego tampak ketika Ayyas mempertahankan diri dalam kesucian dan keimanannya di tengah badai badai kehidupan bernegara bebas, memiliki keyakinan dan keyakinan yang teguh kepada Ya Tuhan, Ayyas tetap percaya diri dan percaya pada anugrah Tuhan untuk umat-Nya. Meski ada sebagian orang yang tidak mengakui keberadaan Tuhan, namun Ayyas selalu berpegang teguh pada kewajiban agama, melaksanakan segala sesuatu yang Tuhan berkenan, dan menjauhi segala larangan-Nya, dan enggan berbuat dosa dan orang berdosa, rela berkorban untuk demi agama dan memberi bantuan.

Kata kunci: Struktur Kepribadian (Id, Ego, Dan Superego)

\section{INTRODUCTION}

Literature is one of the creative works that has imaginative element that describe a human life as an object. Literary work is one of the devices to describe and express the human life, not only in relation to other human beings, with universe, and God. One of the literary works is novel. The appearance of novel is the result of a creative author in processing the complete story of its life in various conflicts.

Novel is a form of literary or fictional story tells of human life in their interaction with the environment and each other. The novel 
as a form of literature is an object that can be enjoyed and at the same time can be assessed. The novel is said to be an object that can be enjoyed, because elements of beauty and message that useful and fun. (Wellek and Warren, 1993: 25).

The researcher chosed the novel Bumi Cinta by Habiburrahman El Shirazy that is from the excess of novel Bumi Cinta as seen from the personality of main character in novel Bumi Cinta helped the reader to define one of the personality problem wherein a Muslim who has a high faith faced with the issue should live in Moscow city which is full of free sex, a figure that should be settled in an apartment with two Russian non- Muslim women. This novel Bumi Cinta is rich with elements of Islamic life and values of the main character's personality that does not deviate, strong determination and not easily swayed by the temptations of the world and women, so the novel Bumi Cinta was very worthy and deserve to analyze.

The problem was analyzed in this study was the personality of Ayyas based on Sigmund Freud Theory (id, ego and super ego) in novel Bumi Cinta by Habiburrahman El Shirazy. In accordance with these problems, the significance of this study was to describe the personality of Ayyas based on the Sigmund Freud theory (id, ego, and superego) in novel Bumi Cinta by Habiburrahman El Shirazy because based on the writer's reseach, novel Bumi Cinta was analyzed by several reviews and never existed to analyzed aspects of personality that leads to the main character by using the theory of Sigmund Freud (id, ego and superego).

The researcher chosen the personality of a character in a literary work to analyze has an important role because through personality of the character the author can portray any character that exist in literature. Without a personality which is reflected through the conflicts between characters in a novel, the literary work is not going to feel alive.

Based on the problem above, the character of Ayyas that contain in novel Bumi Cinta by Habiburrahman El Shirazy was analyzed with psychology aspect based on the theory of Sigmund Freud (id, ego and superego) to find out the personality of the main character. The writer gave a title in this study "The Personality of Ayyas in novel Bumi Cinta by Habiburrahman El Shirazy (Psychology)."

\section{REVIEW OF RELATED LITERATURE}

According to Rene Wellek \& Austin warren (1990: 3) said that "Literature is an creative activity, a work of art. Literature is often said to be a school of life in that the authors tend to comment on the conduct of society and individuals in society. They either point out what they see as important issues in human affairs or propose ideal alternative to the way thing actually are the custom and more of particular social group or individuals their aspirations and values explored and exposed (Taylor, 1981:12). One of the literary work is novel.

Novel is narrative text informing of prose with a long shape that including some figures and fiction event. According to Abrams (1999: 190) said that The term "novel" is now applied to a great variety of writings that have in common only the attribute of being extended works of fiction written in prose. $\mathrm{He}$ also said As an extended narrative, the novel is distinguished from the short story and from the work of middle length called the novelette; its magnitude permits a greater variety of characters, greater complication of plot (or plots), ampler development of milieu, and more sustained exploration of character and motives than do the shorter, more concentrated modes. The novel as a form of literature is an object that can be enjoyed and at the same time can be assessed. Novel as object can be regarded as enjoyed, because the literature (novels) has elements of beauty and message, or dulce et utile termed by Horace, which means that useful and fun (Wellek and Warren, 1993: 25).

Novel is a prose narrative fiction. 
Taylor, (1981 : 46) stated that a prose works of quite some length and complexity which attempts to reflect and express something of the quality or value of human experience or conduct. A novel is almost the same as a short story; they both are included in prose narrative fictions that have similarity in the intrinsic element such as plot, character, theme, setting etc. Gordon W. Allport of Harvard University, as cited by Hewstone, Fincham, and Foster (2005: 294), Personality is a dynamic organisation, inside the person, of psychophysical systems that create the person's characteristic patterns of behaviour, thoughts and feelings.

According to Child, 1968 Miles Hewstone, Frank Fincham, Jonathan Foster (2005: 294) More or less stable, internal factors make one person's behaviour consistent from one time to another, and different from the behaviour other people would manifest in comparable situations.

Both these definitions emphasize that personality is an internal process that guides behaviour. Gordon Allport (1961) makes the point that personality is psychophysical, which means both physical and psychological. Recent research has shown that biological and genetic phenomena do have an impact on personality. Child (1968) makes the point that personality is stable - or at least relatively stable. Child (1968) includes consistency (within an individual) and difference (between individuals) in his definition, and Allport (1961) refers to characteristic patterns of behaviour within an individual. These are also important considerations. So personality is what makes actions, thoughts and feelings consistent (or relatively consistent), and it is also what makes people different from one another.

\section{The Id, Ego, and Superego}

Freud developed a revised theory (the structural model) that describes personality in terms of three constructs: the id, the ego, and the superego (Freud, 1923/1962). Freud emphasizes that the id, ego, and superego are not separate compartments within the mind. They blend together, like sections of a telescope or colors in a painting. For purposes of discussion, however, it is necessary to treat these interrelated constructs one at a time.

\section{The Id}

The id (das Es; literally, the "it") is the only component of personality that is present at birth. It therefore includes all of the instincts, and the total supply of psychic energy. The id is entirely unconscious and represents "the dark, inaccessible part of our personality, a chaos, a cauldron full of seething excitations" (Ewen, 2009: 17).

The id corresponds to Freud's earlier notion of the unconscious (although the ego and superego have unconscious aspects as well). The id is the reservoir for the instincts and libido (the psychic energy manifested by the instincts). The id is a powerful structure of the personality because it supplies all the energy for the other two components. Because the id is the reservoir of the instincts, it is vitally and directly related to the satisfaction of bodily needs. Tension is produced when the body is in a state of need, and the person acts to reduce this tension by satisfying the need. The id operates in accordance with what Freud called the pleasure principle; through its concern with tension reduction, the id functions to increase pleasure and avoid pain. The id strives for immediate satisfaction of its needs and does not tolerate delay or postponement of satisfaction for any reason. The id has no awareness of reality. The only ways the id can attempt to satisfy its needs are through reflex action and wish-fulfilling hallucinatory or fantasy experience, which Freud labeled primary-process thought (Schultz, 2005: 54)

\section{The Ego}

The ego (the word is Latin for ' $I$ ') develops from the id but comes to exercise control over it. The ego provides the individual with the sense 
of self and watches over the instinctual demands of the id, deciding whether, when and how they can be gratified. In most respects the ego plays the role the conscious played in Freud's initial bipartite model, although Freud made clear that some of the monitoring and censoring of the id that the ego carries out is done unconsciously. The ego is the rational part of the mind, the part that reacts to the outside world and allows the individual to adapt to reality, to acknowledge the 'reality principle.' (Reninnson, 2001: 39).

The ego is the logical, self-preservative, problem-solving part of personality. It mediates among the demands of the external world, the id, and the superego, and is largely unconscious. As in Freudian theory, the ego guards against illicit id impulses and an overly severe superego by using various defense mechanisms, including repression, reaction formation, projection, denial of reality, and fantasy (Reninnson, 2001: 40).

\section{The Superego}

The ideas of right and wrong. In everyday language that call this internal morality a conscience. Freud called it the superego. The basis of this moral side of the personality is usually learned by the age of 5 or 6 and consists initially of the rules of conduct set down by our parents. Through praise, punishment, and example, children learn which behaviors their parents consider good or bad. Those behaviors for which children are punished form the conscience, one part of the superego. The second part of the superego is the ego- ideal, which consists of good, or correct, behaviors for which children have been praised. In this way, children learn a set of rules that earn acceptance or rejection from their parents. In time, children internalize these teachings, and the rewards and punishments become self-administered. Parental control is replaced by self- control. As the arbiter of morality, the superego is relentless, even cruel, in its quest for moral perfection. The superego strives neither for pleasure (as does the id) nor for attainment of realistic goals (as does the ego). It strives solely for moral perfection. The id presses for satisfaction, the ego tries to delay it, and the superego urges morality above all. Like the id, the superego admits no compromise with its demands (Schultz, 2005: 56)

\section{Source of Data}

The source of data in this study was novel Bumi Cinta by Habiburrahman El Shirazy which is consist of 546 pages published in 2010 by Imprint Basmala Adikarya Legendaris at Semarang, Jawa Tengah-Indonesia.

\section{Object of Study}

The object of this study was the personality of Ayyas based on Sigmund Freud theory (id, ego and superego) in Bumi Cinta novel by Habiburrahman El Shirazy.

\section{Techniques of Data Collection}

In this study, researcher used some stypes of collecting data technique, they are:

a. Documentation technique, it is used especially for library documentation studies. Sunarto (2001: 155) states that there are many forms of documents/write notes, such as biography, autobiography, daily note, letter, picture, and literary works that have correlation to the topics, which are studied.

In collecting data, the researcher used some steps below:

1. Close reading on the novel is the activity of researcher to read the novel from first page till the last pages. Reading the novel to get a general idea of the overall meaning contained about the personality of main character based on Sigmund Freud (id, ego, and superego) in novel Bumi Cinta by Habiburrahman El Shirazy. Collecting data from the novel quotation by close reading in order to get accurate data

2. References concerning with the focussed of this study in order to support the discussion of personality based on Sigmund Freud (id, ego and superego) 
3. Compiles the selected quotation which show the personality of main character based on Sigmund Freud (id, ego, and superego)

4. Coding every transaction in the novel Bumi Cinta contains the relevant data for the study

\section{Techniques of Data Analysis}

Technique of data analysis was used by the writer to analyze the data is descriptive analysis and content analysis. Content analysis is a study technique to make inferences ( Krippendorf, 1993: 15). It used to describe the personality of Ayyas in novel Bumi Cinta. According to Matthew Miles and Huberman, there are three components to analyze the data, namely:

\section{Data reduction}

Data reduction refers to the process selecting, focusing simplying, abstracting, and transforming the data that appear in the writtenup field notes or transcription (Huberman, 1994: 10). In data reduction step the researcher focussed on the important data and finding theme, and throw the data that is not important. Therefore, the data reduction gave clearer description, so that the researcher was easy to find the data needed. In this data reduction, the researcher focusseed on the personality of Ayyas in novel "Bumi Cinta" based on Sigmund Freud theory (The Id, Ego and Superego).

2. Presentation of data (data display)

Data display is the next step after data reduction. In the qualitative approach, the data display done in short essay. Miles and Huberman state that. "The most frequent form of displaying data for qualitative research data in the past has been narrative text". Data display is an organized, compressed, assembly of information that permits conclusion drawing and action (Huberman, 1994: 11).

Therefore, the data of this research displayed in short description form. It was about the personality of main characters( Ayyas) based on Sigmund Freud theory (The Id, Ego and Superego) in novel "Bumi Cinta" by Habiburrahman El Shirazy.
3. Conclusion drawing and verification

The third of analyzed activity is conclusion drawing and verification is processed or transferred into forms that fit the pattern of problem solving is done (Huberman, 1994: 11).

The conclusion of qualitative research answered of the problem of the research which formulated in the first planning of the research. The conclusion was a new finding that has never been existed yet. The finding was like the description of the object, causal correlation, or theory. The research verified in sense to be confirmed, revised and repeated by the same or different way. The data conclusion refered to the personality of main character based on Sigmund Freud theory (Id, Ego and Superego) in novel "Bumi Cinta".by Habiburrahman.

\section{RESEARCH FINDING AND DISCUSSION Research Finding}

This chapter present the data that was gained during the research carry out. Based to the aimed of the research analyzed the personality that related to the Id, Ego, and Superego of Ayyas character in novel "Bumi Cinta by Habiburrahman El Shirazy". All of the datas those has been gathered during research that focusses on the personality based on Sigmund Freud theory, concerning in Id, Ego, and Superego. Then the researcher described the personality of Ayyas, as follow:

\section{The personality influence by the Id}

The $I d$ unconsciously strives to satisfy basic sexual and aggresive drives, work on the pleasure principle, demanding immediate gratification (pleasure principle). The id presses for satisfaction. Based on Sigmund Freud in Ewen (2009:17), the id transforms biological needs into psychological tension(drives). Its only goal is to gain pleasure by reducing these drives (the aforementioned pleasure principle). The personality seems in Ayyas was when his id wants to see a pretty girl, as in the following quotations: 
I.1) "Nggak tahu ah." Jawab Ayyas. sekilas ia tetap melihat wajah gadis Rusia yang ditunjuk Devid." (Bumi Cinta, 2010: 23) I.2) "I do not know." Ayyas Answered. He still saw the face of the Russian girl designated by Devid in glance."

I.3) "Ada sedikit dalam hati Ayyas mengakui gadis Rusia yang ia lihat sekilas itu memang jelita." (Bumi Cinta, 2010: 23)

I.4) "In his little heart hearts Ayyas confessed if the Russian girl that he saw was beautiful although it was in glance.

The id attempts to satisfy its needs are through reflex action and wish-fulfilling hallucinatory. Both of the quotes above show how Ayyas is very happy when he saw a pretty girl, his desire to see the beautiful girl could not be avoid, even though he tried to resist. The $i d$ strives for immediate satisfaction of its needs and it does not tolerate delay or postponement of satisfaction for any reason. Id in Ayyas prompted him to do something that could make him glad, as he did in the above quote. He tried to fulfill his desire by seeing the girls although in glance.

\section{a. The personality influenced by the Ego}

The ego functions as the "executive" and mediates the demands of the Id and Superego. Based on Freud in Reninnson (2001: 39), the Ego is the rational part of the mind, the part that reacts to the outside world and allows the individual to adapt to reality, to acknowledge the 'reality principle'. The ego also controls what goes in and awareness of what would be done. Emotions occur only in the ego. His ego influences Ayyas personality and make him to express his anger to Devid, as in quotation bellow:

\section{E. 1) "Mungkin dengan tinggal bersama perempuan kau merasa aku aman. $Y a$, mungkin tubuh dan hartaku}

aman. Tapi bagaimana dengan imanku Dev? Justru imanku sangat terancam. Jika tinggal dengan bule yang laki-laki aku malah akan merasa aman!" Kata Ayyas tegas. (Bumi Cinta, 2010: 36)

Maybe living together with a woman, do you think I'm safe?. Ok, perhaps my life and my property are safe, but what about my faith? Precisely, my faith will be threaten. If I live with a male caucasians instead a girl, I think I will be safe!" Ayyas said strickly."

The ego system in Ayyas feels anxiety because he will stay together with unfamiliar girl in the apartement. He feels his faith will be shaky if he lives with the girl in the apartement. His body and secure may be safe but how about his faith? Because of the impuls from his ego, that's why Ayyas tells Devid about his anxiety directly, how he feels about his faith will be treat if he lives with the girl in the apartement. The ego develops from the id but come to

exercise control over it. The ego provides the individual with the sense of self and watches over the instinctual demand of the id.

When he faced Yelena, he tries to reduce his tension that cause of his $i d$ by using his $e g o$, as in the following quotation:

E.2) "Ayyas diam membisu. Ia menata hati dan pikirannya. Ia ambil nafas perlahanlahan untuk menghilangkan kegugupannya. Perlahan ia sudah bisa mulai menguasai diri dan pikirannya yang sempat oleng. (Bumi Cinta, 2010: 50)

"Ayyas just kept silent, he managed his heart and mind. He takes a breath slowly to lose his nervous. Slowly, he can control himself back and his mind almost shaky."

The above quotation shows how the ego system of Ayyas works to control the effect of his id 
which make him was in uncomfortable position. Ego system of Ayyas makes an action immediately. He tries to organize his hearts and minds slowly, so that he can control his id. The ego is the rational part of the mind, the part that reacts to the outside world and allows the individual to adapt to reality, to acknowledge the 'reality principle'.

His ego also created when Yelena offered him to go along and deliver Ayyas to MGU, appear in the following quotation:

E.3) "Ayyas diam, ia tidak bisa menjawab.Mau menjawab ya, berarti akan jalan berdua sama Yelena seperti orang pacaran. Kalau bilang tidak, jujur ia belum tahu Moskwa sama-sekali." (Bumi Cinta, 2010: 60)

"Ayyas silent, he can not answer. Want to say yes, will walk together with Yelena like the courting. If he says no, honestly he did not know Moscow at all."

The above quotation refers to Ayyas ego. System ego of Ayyas appears when he in judgment to accept Linor's offer or not. His ego is very careful to make a decision. The ego is the rational master of personality. Because it is aware of reality, the ego decides when and how the $i d$ instincts can best be satisfied.

His ego attempted again when he arrived at MGU, he met with Anastasia Palazzo, an assistant lecture of Prof. Tomskii and she will replace Prof. Tomskii as his adviser. The ego serves two masters, the id and reality and is constantly mediating and striking compromises between their conflicting demands.

\section{b. The personality influence by the Superego}

Superego is the third system of personality of someone who contains the moral aspect. Conscience associated with social environments and has norms that constitute the control or censorship of impulses that come from outside the $I d$. Based on Freud and Psychonanalysis in Reninnson (2001:42), Superego demands perfection of the ego, it meets impossible ideals of though and behaviour. This is the perfection of pleasure because of Superego can also regarded as a moral rather than a personality. Determine whether something is right or wrong, appropriate or not. Superego requires that certain impulses of the $I d$ realized, while the impulses those are inconsistent with the moral values order are met. Therefore, there are some sort of personality between the Id and Superego which is the implementation of which must be able to meet the demands of both aspects in balanced personality. If the Ego fails to keep balance, then the individual will suffer the personality.

Has not arrived yet in Moscow, he was already entangled by slander women, he look to the girl that he not known unconsciously, but his superego appears suddenly and revive him. As in the following quotation:

\section{S.1) "Ayyas tiba-tiba begitu merasa berdosa} kepada Ainal Muna, gadis manis dari Kaliwungu Kendal yang sudah dipinangnya dan ia telah berjanji untuk setia padanya." (Bumi Cinta, 2010: 2324)

"Ayyas felt guilty to Ainal Muna,who is a sweet girl from Kendal Kaliwungu who proposed to be his wife and he promised to faithful to her."

The above quotation shows how the superego affects Ayyas's personality, he felt guilty to Ainal Muna, a sweet woman who propossed by him as his wife. He feels guilty to Ainal muna because he think about another girl. He guess if he betrayed Ainal Muna his beloved fiancee, because he saw another beautiful girl before he arrived in Rusia. The guilty feelings to Ainal Muna is the effect of his superego, because the guilty feelings to other people is a form of moral values. Superego also regarded as a moral rather than a personality. Determine whether something is right or 
wrong, appropriate or not.

Ayyas felt his faith becomes very weak when he was in Moscow. There's nothing that can help him, except pray to God, as in the following quotation:

S.2) "Ia merasa tidak punya benteng dan senjata apapun untuk menjaga imannya, kecuali berdoa memohon kepada Allah, agar iman yang ada di dalam hatinya tidak tercabut dalam kondisi apa pun." (Bumi Cinta, 2010: 40)

He felt he was blank, he has nohing such as fortres and weapon to fort his faith, except pray to God, in order the faith in his heart was not depriving in any circumstances."

S.3) Ayyas merasa ujian itu datang juga. Makan berdua dengan perempuan cantik seperti Yelena? Ia berdoa kepada Allah agar menjaga diri dan imannya." (Bumi Cinta, 2010: 50)

"Ayyas felt the test was coming too. Eat together with a beautiful woman like Yelena? He always pray to God to protect himself and his faith."

S.4) "Duhai Allah, jauhkan hamba-Mu dari kejahatan dan fitnah yang ditimbulkan oleh wajah jelita nonik-nonik muda Rusia." (Bumi Cinta, 2010: 81)

"Oh God, keep away your servant from evil and slander that caused by a lovely face of young Russian girls."

S. 5) "Ayyas menangis memohon kepada Allah agar tidak diuji dengan ujian yang ia tidak mampu melewatinya dengan selamat. Ia minta dilindungi oleh Allah, diteguhkan hatinya untuk tetap lurus memegang ajaran Islam yang mulia." (Bumi Cinta, 2010: 115)

"Ayyas cries and begged to God in order not to be tested with a test that he was not able to pass safely. He asked to protected by God, strengthened his heart to keep straight to hold Islamic teachings."

Fourth of the quotations above show how the superego of Ayyas, because when someone remembers to God and ask for help to estrange them from bad thing. Superego is the perfection of pleasure.

All of his pray that he asked to God, he hopes if he wouldn't face a bad thing a again, but it is lose when he witnessed Linor intercourse with her lover Sergei that is not supposed to be. When they feel Ayyas bother them with the murattal sound that Ayyas played from his computer, they approached Ayyas's room. Ayyas became angry, so that there was a fight between both of them. But Ayyas did not regret at all cause do a fight with Sergei.

\section{B. DISCUSSION}

As stated in the previous chapter, where Gordon W. Allport of Harvard University, as cited by Hewstone, Fincham, and Foster (2005: 294), Personality is a dynamic organisation, inside the person, of psychophysical systems that create the person's characteristic patterns of behaviour, thoughts and feelings. Freud developed a revised theory (the structural model) that describes personality in terms of three constructs: the id, the ego, and the superego (Freud, 1923/1962). Freud emphasizes that the id, ego, and superego are not separate compartments within the mind. The id transforms biological needs into psychological tension (drives). Its only goal is to gain pleasure by reducing these drives (the aforementioned pleasure principle). The ego is the only component of personality that can interact with the environment. It is logical and rational, and forms realistic plans of action designed to satisfy the needs of the id. Although the ego is also interested in pleasure, it suspends the pleasure principle in favor of the reality principle and delays the discharge of 
tension until a suitable object can be found. Based on Freud and Psychoanalysis in Nick Reninnson (2001: 42), the super- ego demands perfection of the ego, that it meet impossible ideals of thought and behaviour. This study was conducted in order to reveal the personality of Ayyas character in novel "Bumi Cinta by Habiburrahman El Shirazy". Based on the datas above, the researcher was found 55 (fifty five) aspects of personalities that happened in Ayyas character, consist of 19 aspects of $I d, 12$ aspects of Ego, and 24 aspects of Superego. Seen that Ayyas personalities.

First, the Id. The Id (biological aspects) is an original personality system. Id does not look right or not though to an act. So, Id does not look at all the things those are objective, but rather to things that are subjective in reality. Id dominant to be defuse tensions in human beings in Ayyas charcter. Id aspect in Ayyas that influence his personality is when he conducted his research to Rusia while there are so many beautiful girls in Rusia, and he can not avoid to do not see the girl, he tries to satisfy his desire to see the girls although in glance. After he saw the beautiful girls and lives with both of girls in the apartemen, he is often getting a shock than pleasure. His id affected unpleasure thing than a good thing. He is getting shocked when he saw Yelena dress that not cover her genetalia, and he also getting shocked when he saw Linor and his boy friend did a bad thing in their

apartement. He also getting shocked when anastasia kissed him, all of his shock is the influence of his $i d$, because the $i d$ affected a tension like shock, surprise and reflext action. Because of his strong desire to move from the apartement to avoid the bad thing, he found his new life and can life freely without worried about the women's slander. Before he is back to Indonesia, he wants to give a good impression for the people whose knows in the Moscow, one of them is teach both of grand children of teacher at Embassy to read Qur'an and learn about Islam religion. After Linor is convert and asked him to be his husband, Ayyas loved Linor so much, because of $i d$, he wants to safe Linor and did want Linor died because of the shooting. Id was influenced Ayyas personality in his everyday life.

Second, the Ego (psychology) is the executor of the personality. In connection with the conflict, the ego acts as a means of thinking and executed of tensions in human beings. Ego in person produces reality with an action plan that has been develoved through the mind and intellect. The ego cases when he always be carefull in take a decision, he always afraid if his faith can be shaky by the slander of women. The ego aspect of Ayyas character was up and down in his everyday life.

Third, the Superego (sociological aspect) is aspects relating to the social background of personality. In this case, the superego was as control of their impulses of the $i d$ and the ego of human beings who have experience conflict. Superego can also be regarded as a moral

aspect of personality, function of determining wheter something is good or bad. The third aspect of personality is Superego, superego dominating Ayyas personality, Ayyas be able to think clearly when he was in disttress. He was able to resist impuls $i d$ in his personlity. He also always remembers to God and asked a help for him, implementing everything that God approves, and stay away from all His prohibitions, and reluctant to commit sin and sinners that's why Ayyas always can reduce his id and ego with his superego. Ayyas also defends in the sanctity himself and his faith in the midst of the storms of free life country. Having a firm belief and faith to God. Ayyas remains confident and believe in the grace of God to His people, although there are some people who does not acknowledge the existence of God. Willing to sacrifice for the sake of religion. In Ayyas itselves formed heroism in defense his religion and give some help. Helping nature is not only related to the social dimension, but also includes the divine world. So the superego of Ayyas influence in his daily activities. 


\section{CONCLUSION AND SUGGESTION}

This is the final consideration of this study. In this chapter, the researcher will draw a conclusion the personality of main character especially Ayyas in novel Bumi Cinta by Hiburrahman El Shirazy.

\section{Conclusion}

In the previous chapter, the researcher has explored the data findings and interpreted them based on the relevant theories mentioned in chapter II. Based on the focus of the present study, the researcher concludes: Id, Ego and Superego to reveal the personality of Ayyas charcter. Finally, at the last conclusion is about the personality of Ayyas based on Sigmund Freud theory: id, ego and superego. Those three are working inside the human body. The personality of Ayyas sometime influence by the id, ego and superego. Through the intraction with many other people around him, based on the analysis (section 4) in his personality, concluded that the personality of Ayyas is more dominant influenced by the superego than the id, or ego.

\section{Suggestion}

Based on the result of this research, there are several sugesstions present by the researcher that Readers appreciate the interest and should continue to be cultivated because of the many benefits that can be drawn from the literature, both as a means to entertain themselves as well as insight for the reader.

Then, this study can be used as a basis for the next researcher in the future. As well as materials that are worthy of the truth of the theory developed by researchers to match with the results of the study expected. Given the novel Bumi Cinta is contained with many personalities of each characters and religion values, so the next researchers should be able to assess the novel with other literary approach

\section{BIBLIOGRAPHY}

Abrams, M. H. 1999. A Glosory of Literary Terms: Seventh Edition. Cornel Universty. Heinle and Heinle:
Tmomson Learning.

Agus Wartiningsih. 2012. Kepribadian Tokoh Dalam Novel Perahu Kertas Karya Dewi Lestari: Analisis Psikologi Sastra. A Thesis. Fkip Untan Pontianak. Pontianak.

Bogdan, Robert and Tasylor, Steven J, 1975. Introduction of Qualitative Research Methode. New York, Brisbane Toronto, Singapore: John Wiley \& Sons

Bogdan, C and Biklen. Knopp. 1982 (qualitative Research for Education.

An Introduction to Theory and Method. Bosto: Allyn \& Bacon

Schultz P. Duane. 2005. Theory of Persoanality.Eigth Edition. Sydney Ellen Schultz. Thomson Learning

El Shirazy, Habiburrahman. 2010. Bumi Cinta. Semarang: Author Publising Ewen B. Robert. 2009: An Introduction to Theories of Personality. 7th

Edition. New York. Psychology Press

Hurlock, Elizabet.B. 1979. Personality Development. New Delhi: Tata Micgraw

Krippendorf, Klauss. 2003. Content Analysis: An Introduction to It's Methodology. Jakarta: Raja Grafindo Persada

Milles, Matthew dan Hubberman. 1992. Analisis Data Kualitatif. Jakarta; Indonesia University press

Miles Hewstone, Frank Fincham, Jonathan Foster. 2005. Psychology (BPS Textbooks in Psychology. USA: Blackwell

Nick Rennison. 2001.FREUD \& 
PSYCHOANALYSIS. USA: Trafalgar Square

Newmark, Peter. 1998. A Text Book of Translation. London: Prentice Hall International.

Nur Mauludiyah. 2009. Kepribadian Tokoh Roda Savitri Darsono Dalam Novel Misteri Sutra Yang Robek Karya S. Mara G. Un Publised Thesis, Universitas Negeri Malang. Malang.

Sunarto. 2001. Metode Penelitian Ilmu Sosial dan Pendidikan. Surabaya: Unesa University press

Taylor. 1981. The Historical Evidence for the virgin Birth. London: At the Clarendon Press.

Wellek, Rene \& Weren, Austin.1990. Theory of Literature (di Indonesiakan oleh Melani Budiantara). Jakarta, PT Gramedia. 